\title{
Eccrine spiradenoma mimicking a painful traumatic neuroma: case report
}

\author{
Katelyn Donaldson, BS, ${ }^{1,2}$ Gretchen Scott, RN, BSN, ${ }^{2}$ Fredric K. Cantor, MD, ${ }^{2}$ \\ Nicholas J. Patronas, MD, ${ }^{3}$ Martha Quezado, MD, ${ }^{4}$ and John D. Heiss, MD ${ }^{2}$

\begin{abstract}
${ }^{1}$ University of Vermont College of Medicine, Burlington, Vermont; ${ }^{2}$ Surgical Neurology Branch, National Institute of Neurological Disorders and Stroke, National Institutes of Health; ${ }^{3}$ Radiology and Imaging Sciences, Warren Grant Magnuson Clinical Center, National Institutes of Health; and ${ }^{4}$ Department of Pathology, National Cancer Institute, National Institutes of Health, Bethesda, Maryland
\end{abstract}

Diagnosing and treating patients with persistent neuropathic pain associated with peripheral nerve lesions can be challenging. The authors report the rare case of a painful eccrine spiradenoma treated as a traumatic neuroma for many years because of a history of acute trauma, the presence of a tender palpable mass, and symptoms of allodynia. Surgical excision of the neoplasm completely relieved the pain and hypersensitivity that 2 prior surgeries and other nonsurgical treatments failed to resolve. The diagnosis of eccrine spiradenoma was not established until resection and histopathological analysis of the tissue. This case highlights the need to develop and consider an extensive list of differential diagnoses, including eccrine spiradenoma, for peripheral nerve lesions that fail to respond to treatment.

https://thejns.org/doi/abs/10.3171/2017.5.JNS162999

KEY WORDS eccrine spiradenoma; neuropathic pain; neuroma; peripheral nerve

$\mathrm{T}$ HE presence of focal tenderness over a peripheral nerve accompanied by distal neuropathic findings suggests the presence of a neuroma. Here, we describe the case of a 34-year-old woman with posttraumatic and focal neuropathic pain and tenderness at the wrist persisting for almost 15 years despite 2 surgeries, transcutaneous electrical nerve stimulation (TENS), and hand therapy. Exploration and excision of an eccrine spiradenoma led to complete relief.

\section{Case Report}

History

When this patient was 19 years old, she collided with a runner, fell, and suffered bruises and tenderness in multiple areas. Two weeks later, she noticed that the ulnar aspect of her right wrist remained tender to mild pressure. Subsequently, she noticed pain in that area while swimming and felt a small subcutaneous tender lump. Her hypersensitivity to mild pressure gradually worsened, and by the time the patient was 25 years old, the hypersensitivity was accompanied by "shooting pain" radiating to the ulnar side of her hand that prevented her from wearing long sleeve shirts and sweaters. After an initial surgical procedure that excised thickened synovium near the extensor carpi ulnaris tendon sheath and dorsal cutaneous branch of the ulnar nerve, the patient experienced minimal but transient improvement. She then underwent several months of desensitization hand therapy and TENS without improvement. Her next surgery was a neurolysis and collagen conduit wrapping of the dorsal cutaneous branch of the ulnar nerve. Immediately after surgery, the patient's pain and hypersensitivity improved but were accompanied by numbness and tingling along the ulnar aspect of the wrist. After about a month, her allodynia became severe again.

The patient presented to our institution when she was 34 years old with persistent allodynia. On examination, the lump was still extremely hypersensitive to light touch. Mild compression of the tender mass produced a burning, stabbing sensation with distal radiation. Distal to the tender area, pinprick and touch sensations were slightly decreased on the dorsal aspect of the hand, with pinprick eliciting tingling. Cold sensation was preserved. There was no weakness or atrophy.

MRI of the right wrist revealed an ovoid lesion, hyperintense on T2-weighted images (Fig. 1), that abutted the dorsal cutaneous branch of the ulnar nerve, producing focal nerve edema.

\section{Operation}

Microscopic surgical reexploration of the right wrist incision revealed an amber, translucent, ovoid lesion that

ABBREVIATIONS CK7 $=$ cytokeratin $7 ;$ TENS $=$ transcutaneous electrical nerve stimulation.

SUBMITTED November 30, 2016. ACCEPTED May 15, 2017.

INCLUDE WHEN CITING Published online October 27, 2017; DOI: 10.3171/2017.5.JNS162999. 


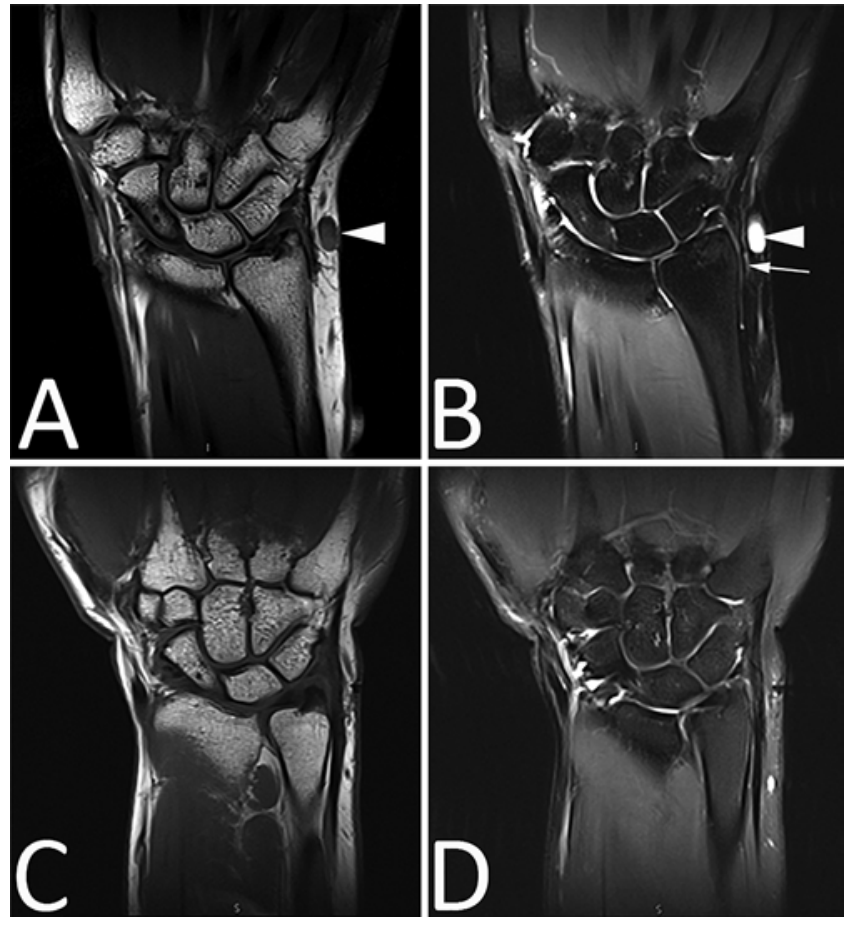

FIG. 1. Preoperative and postoperative MR images of the right wrist lesion. Preoperative coronal fat-suppressed MRI slices demonstrate the presence of a lesion (arrowhead) and nerve (arrow) along ulnar aspect of wrist on T1-weighted (A) and fat-suppressed T2-weighted (B) images. Postoperatively, no evidence of the lesion is visible on T1-weighted (C) and T2-weighted (D) coronal MRI slices.

was rubbery in consistency. A tiny fascicle of the dorsal cutaneous branch of the ulnar nerve was transected where it entered the deep side of the lesion. The lesion was removed en bloc with no observable remnants.

\section{Postoperative Course}

Postoperative MRI performed 2 months after surgery documented complete removal of the lesion and resolution of the nerve edema (Fig. 1). The patient has remained pain free throughout 1 year after surgery.

\section{Pathological Findings}

The lesion was grossly an ovoid, well-defined, firm mass. The grayish-brown specimen was sectioned. Sections stained with $\mathrm{H} \& \mathrm{E}$ revealed a highly cellular lesion with adnexal basophilic cells and some lymphocytic infiltrate consistent with eccrine spiradenoma. Tumor cells were positive for cytokeratin 7 (CK7) by immunohistochemical staining (Fig. 2).

\section{Discussion}

By description, this patient's collision appeared to be a significant multifocal injury. It is not surprising that the patient assumed that her painful nodule resulted from this trauma. The subsequent symptom progression and neurological findings were consistent with the presence of a posttraumatic neuroma. Clinical history and examination findings are usually sufficient to diagnose a traumatic neuroma, although other causes of painful nerve pathology
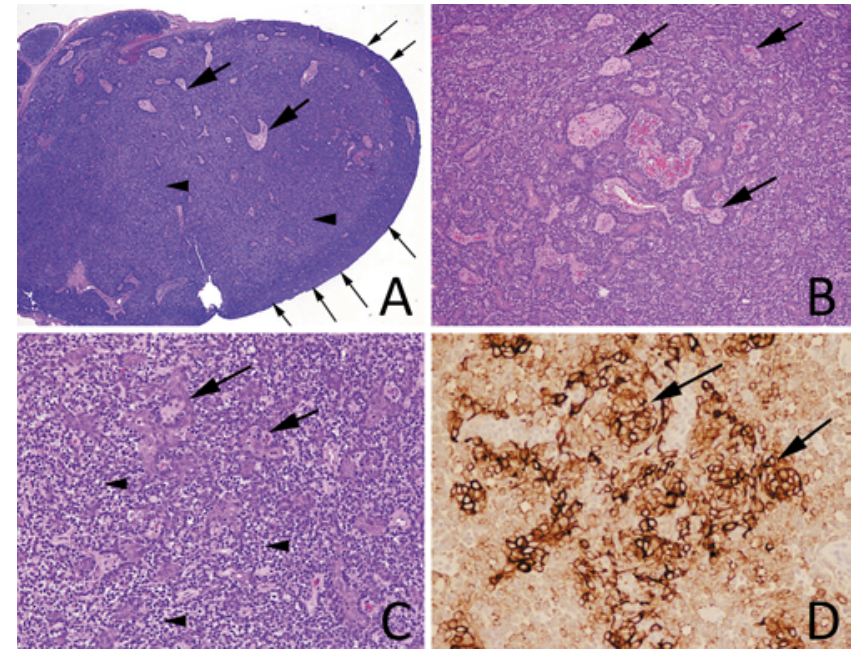

FIG. 2. Histopathological findings. A: Low-power photomicrograph highlighting the presence of the prominent fibrous capsule (thin arrows) surrounding a well-circumscribed, cellular neoplasm with basophilic cells (arrowheads) disposed in solid sheets or forming tubules (thick arrows). B and C: Higher-power images demonstrate dense basophilic lymphocytic infiltration of the tumor (arrowheads) and the presence of eccrine sweat glands (thick arrows). D: On immunohistochemical analysis, tumor cells are positive (thick arrows) for CK7. H \& E (A-C); original magnification $\times 40(A), \times 100(B), \times 200(C$ and $D)$.

should be kept in mind, including ganglion cyst, schwannoma, neurofibroma, malignant peripheral nerve sheath tumor, lipofibromatous hamartoma, infectious lesion, inflammatory lesion, and eccrine spiradenoma. MRI characteristics may provide further diagnostic information. The intraneural edema and swelling within a traumatic neuroma produces inhomogeneous hypointensity on T1weighted images and hyperintensity on T2-weighted and STIR images. ${ }^{22}$ Traumatic neuromas have variable enhancement on postcontrast imaging. An eccrine spiradenoma appears on MRI as a subcutaneous cystic or solid mass, with low signal intensity on T1-weighted images and intermediate to high signal intensity on T2-weighted and STIR images and enhancement on contrast imaging. ${ }^{7,11}$ On ultrasonography, traumatic neuroma and eccrine spiradenoma are hypoechoic, but a traumatic neuroma disrupts the normal fibrillar pattern of the nerve, whereas an eccrine spiradenoma rests outside the nerve. , $22^{2}$ In our case, gross and histopathological examination of the specimen demonstrated typical findings of eccrine spiradenoma (Table 1). ${ }^{1,2,5-7,10,12,14,15,17,18,20}$ On H \& E-stained sections, the tumor was a well-circumscribed adnexal neoplasm with basophilic cells. On immunohistochemical analysis, the tumor stained positive for CK7, which stains the secretory coil of the eccrine gland. ${ }^{13}$ Spiradenomas and cylindromas are both CK7 positive, but the histology was consistent with eccrine spiradenoma. Eccrine spiradenoma contains large lobules with a solid tubular pattern while cylindroma has irregularly shaped islands of cells separated by a hyalin stroma. ${ }^{4}$ Epithelial cells and lymphocytes are seen with eccrine spiradenoma compared with monomorphic cells in dermal cylindroma (Fig. 2). ${ }^{19}$

Neuromas can develop from cutaneous nerves as a consequence of chronic irritation, pressure, stretch, abnormal 
TABLE 1. Differential diagnosis of a peripheral nerve lesion

\begin{tabular}{|c|c|c|c|c|}
\hline Disease & Clinical Presentation & MRI Appearance & Gross Appearance & Histology \\
\hline $\begin{array}{l}\text { Traumatic neu- } \\
\text { roma }\end{array}$ & $\begin{array}{l}\text { History of acute trauma; } \\
\text { painful \& tender; gener- } \\
\text { ally develops 1-12 mos } \\
\text { after transection }{ }^{14}\end{array}$ & $\begin{array}{l}\text { Hypointense on T1WI; intermediate to } \\
\text { hyperintense on T2WI \& STIR; variable } \\
\text { contrast enhancement }{ }^{1}\end{array}$ & Small w/ a firm texture & $\begin{array}{l}\text { Large cluster of haphazard } \\
\text { microfascicles }^{5}\end{array}$ \\
\hline Ganglion cyst & $\begin{array}{l}\text { Commonly affects wrist; } \\
\text { often painful }\end{array}$ & $\begin{array}{l}\text { Hypointense on T1WI, hyperintense on } \\
\text { T2Wl; cyst wall enhancement }{ }^{14}\end{array}$ & $\begin{array}{l}\text { Smooth, white, translu- } \\
\text { cent mass; connected } \\
\text { to tendon sheath }{ }^{15}\end{array}$ & $\begin{array}{l}\text { Cyst wall of collagen fibers } \\
\& \text { w/o epithelial lining }{ }^{15}\end{array}$ \\
\hline Schwannoma & $\begin{array}{l}\text { May be painful; most com- } \\
\text { mon peripheral nerve } \\
\text { tumor; sporadic single } \\
\text { neoplasm except in NF2 }\end{array}$ & $\begin{array}{l}\text { Isointense to slightly hyperintense on T1WI; } \\
\text { hyperintense on T2WI \& STIR; small } \\
\text { tumors enhance homogeneously; large } \\
\text { tumors inhomogeneously; may be ec- } \\
\text { centric to nerve }^{14}\end{array}$ & $\begin{array}{l}\text { Smooth, well-encapsu- } \\
\text { lated, firm, tan mass }\end{array}$ & $\begin{array}{l}\text { Schwann cell composition } \\
\text { with biphasic architecture } \\
\text { pattern (Antoni } A \& B)^{20}\end{array}$ \\
\hline Neurofibroma & $\begin{array}{l}\text { May be painful; sporadic } \\
\text { single neoplasm except } \\
\text { in NF1 }\end{array}$ & $\begin{array}{l}\text { Similar appearance to schwannoma but w/ } \\
\text { central nerve location }{ }^{14}\end{array}$ & $\begin{array}{l}\text { Well-circumscribed tan- } \\
\text { grayish lesion grossly }\end{array}$ & $\begin{array}{l}\text { Mixture of Schwann cells \& } \\
\text { fibroblasts; intratumoral } \\
\text { nerve fibers differenti- } \\
\text { ates from schwannoma }\end{array}$ \\
\hline $\begin{array}{l}\text { Malignant pe- } \\
\text { ripheral nerve } \\
\text { sheath tumor }\end{array}$ & $\begin{array}{l}\text { Characterized by rapid } \\
\text { change in pain or size of } \\
\text { tumor }^{6}\end{array}$ & $\begin{array}{l}\text { Similar to schwannoma \& neurofibroma; } \\
\text { size }>5 \mathrm{~cm} \text { \& infiltrating margins suggest } \\
\text { malignancy }{ }^{18}\end{array}$ & $\begin{array}{l}\text { Firm grayish-tan tumor } \\
\text { grossly; generally } \\
\text { large }(>5 \mathrm{~cm}) \text {; necro- } \\
\text { sis \& hemorrhage }{ }^{20}\end{array}$ & $\begin{array}{l}\text { Highly cellular spindle cell } \\
\text { mass }^{20}\end{array}$ \\
\hline $\begin{array}{l}\text { Lipofibromatous } \\
\text { hamartoma }\end{array}$ & $\begin{array}{l}\text { Upper limbs usually af- } \\
\text { fected; commonly affects } \\
\text { median nerve; true } \\
\text { macrodactyly associa- } \\
{\text { tion; }{ }^{5} \text { slow growing }}^{2}\end{array}$ & $\begin{array}{l}\text { Nerve bundles hyperintense; fat component } \\
\text { hyperintense on T2Wl; pathognomonic } \\
\text { "cable-like" mass }{ }^{14}\end{array}$ & $\begin{array}{l}\text { Often encapsulated; } \\
\text { composed of adipose } \\
\text { tissue; easily sepa- } \\
\text { rated from nerve }\end{array}$ & $\begin{array}{l}\text { Fibroadipose tissue } \\
\text { interspersed w/ nerve } \\
\text { fascicles, enlarging the } \\
\text { epineurium }{ }^{2}\end{array}$ \\
\hline $\begin{array}{l}\text { Infectious lesions, } \\
\text { e.g., Mycobac- } \\
\text { terium leprae }\end{array}$ & $\begin{array}{l}\text { Cutaneous \& ulnar nerve; }{ }^{10} \\
\text { developing country expo- } \\
\text { sure; signs of infection }\end{array}$ & $\begin{array}{l}\text { Isointense on T1Wl; hyperintense on T2WI } \\
\text { \& STIR; dense enhancement; nerve } \\
\text { enlargement }{ }^{12}\end{array}$ & $\begin{array}{l}\text { Localized enlargement } \\
\text { of peripheral nerve }{ }^{10}\end{array}$ & $\begin{array}{l}\text { Destruction of nerve fibers } \\
\text { \& extensive loss of } \\
\text { myelin }^{5}\end{array}$ \\
\hline $\begin{array}{l}\text { Inflammatory } \\
\text { pseudotumor } \\
\text { of nerve }\end{array}$ & Always painful & $\begin{array}{l}\text { Hypointense on T1Wl; hyperintense on } \\
\text { T2Wl; enhancement of enlarged nerve }{ }^{17}\end{array}$ & $\begin{array}{l}\text { Rare cause of peripheral } \\
\text { nerve enlargement (5 } \\
\text { reported cases) })^{17}\end{array}$ & $\begin{array}{l}\text { Connective tissue \& } \\
\text { chronic inflammatory cell } \\
\text { infiltrate }\end{array}$ \\
\hline $\begin{array}{l}\text { Eccrine spirad- } \\
\text { enoma }\end{array}$ & Painful \& tender mass & $\begin{array}{l}\text { Subcutaneous mass; hypointense on T1Wl; } \\
\text { intermediate to hyperintense on T2WI \& } \\
\text { STIR; homogeneous enhancement, }\end{array}$ & $\begin{array}{l}\text { Ovoid, well-defined, firm } \\
\text { mass }\end{array}$ & $\begin{array}{l}\text { Well-circumscribed adnexal } \\
\text { neoplasm w/ basophilic } \\
\text { cells; CK7 positive }\end{array}$ \\
\hline
\end{tabular}

NF1 = neurofibromatosis Type 1; NF2 = neurofibromatosis Type 2; T1WI = T1-weighted imaging; T2WI = T2-weighted imaging.

regeneration of nerve lesions, laceration, crush injury, or blunt trauma. ${ }^{23}$ Neuromas present a particular management challenge as they are often refractory to medical therapy or injected agents. A variety of surgical treatments are available, including transposition of the nerve into local muscle or vein, burying the neuroma, covering the neuroma with vascularized soft tissue or flaps, and nerve stripping, but these interventions produce varying outcomes and may not relieve the symptoms. ${ }^{21}$ Excision can be considered if no significant deficit would result.

Eccrine spiradenoma is a rare neoplasm originating from sweat glands. ${ }^{9}$ In the initial classification by Kersting and Helwig, more than $90 \%$ of tumors were described as ovoid, well-defined, and relatively firm, which matches the gross description of the lesion in our case. In addition, 91\% of their patients experienced pain or tenderness or both. Most eccrine spiradenomas are benign tumors, but, as of 2011, 102 cases of malignant transformation had been reported. ${ }^{3}$ Eccrine spiradenomas can be found as solitary or multiple lesions. The mechanism by which eccrine spi- radenoma causes pain is uncertain. A previous case report identified thickened nerve fibers in the tumor capsule and connective tissue of the stroma, which were positive for S100 and neuron-specific enolase staining. ${ }^{16}$ The authors hypothesized that these nerve fibers were hyperexcitable and were stimulated by pressure or mild, cutaneous sensory stimuli. In our patient, we hypothesize that pain arose from the eccrine spiradenoma compressing the dorsal cutaneous branch of the ulnar nerve against the ulna (Fig. 3) as well as allodynia of the skin overlying the lesion.

Total excision is the standard treatment of eccrine spiradenoma. In this case, previous treatment to surgically insulate or cushion the presumed neuroma from trauma failed because of the persistence of the underlying eccrine spiradenoma. Excision of the lesion eliminated the possibility of the tumor later undergoing malignant degeneration. ${ }^{3}$

\section{Acknowledgments}

This work was supported by the Intramural Research Program 


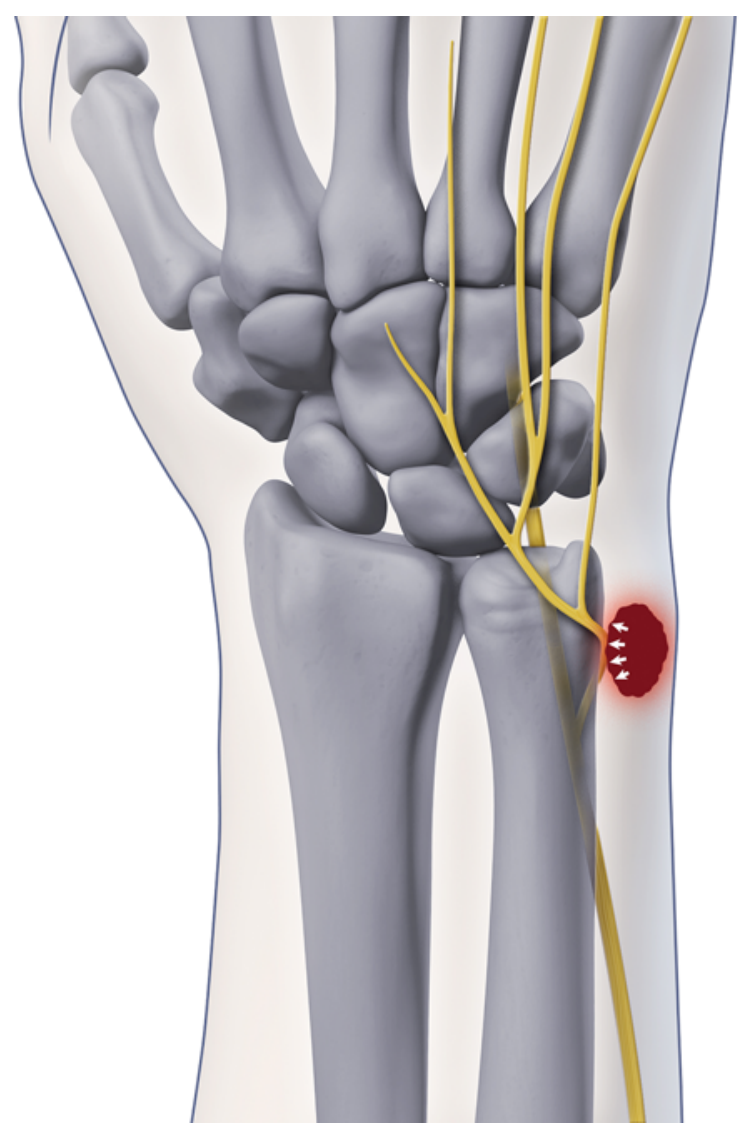

FIG. 3. Drawing demonstrating the presumed mechanism of neuropathic pain. Chronic pain arose from the eccrine spiradenoma (red oval) compressing the dorsal cutaneous branch of the ulnar nerve (yellow structure) against the ulna. Palpating the lesion increased compression of the nerve between the inner surface of the tumor (white arrows) and bone and exacerbated the pain significantly. Illustration by NIH Medical Arts Design Section.

at the National Institute of Neurological Disorders and Stroke at the National Institutes of Health. The drawing in Fig. 3 was kindly provided by Alan Hoofring, MS, MA, of the National Institutes of Health Medical Arts Design Section, Bethesda, Maryland.

\section{References}

1. Ahlawat S, Belzberg AJ, Montgomery EA, Fayad LM: MRI features of peripheral traumatic neuromas. Eur Radiol 26:1204-1212, 2016

2. Al-Jabri T, Garg S, Mani GV: Lipofibromatous hamartoma of the median nerve. J Orthop Surg 5:71, 2010

3. Andreoli MT, Itani KMF: Malignant eccrine spiradenoma: a meta-analysis of reported cases. Am J Surg 201:695-699, 2011

4. Gerber JE, Descalzi ME: Eccrine spiradenoma and dermal cylindroma. J Cutan Pathol 10:73-78, 1983

5. Golan JD, Jacques L: Nonneoplastic peripheral nerve tumors. Neurosurg Clin N Am 15:223-230, 2004

6. Gupta G, Mammis A, Maniker A: Malignant peripheral nerve sheath tumors. Neurosurg Clin N Am 19:533-543, v, 2008

7. Han YD, Huan Y, Deng JL, Zhang YG, Zhang CH: MRI appearance of multiple eccrine spiradenoma. Br J Radiol 80:e27-e29, 2007

8. Jin W, Kim GY, Lew BL, Yang DM, Kim HC, Ryu JK, et al: Sonographic findings of an eccrine spiradenoma: case report and literature review. J Ultrasound Med 27:813-818, 2008
9. Kersting DW, Helwig EB: Eccrine spiradenoma. AMA Arch Derm 73:199-227, 1956

10. Kumar K: Surgical management of leprous ulnar neuritis. Clin Orthop Relat Res (163):235-242, 1982

11. Lee HH, Park SH, Choi HY, Park HK: Eccrine spiradenoma arising in the breast misdiagnosed as an epidermal inclusion cyst. Korean J Radiol 12:256-260, 2011

12. Martinoli C, Derchi LE, Bertolotto M, Gandolfo N, Bianchi S, Fiallo P, et al: US and MR imaging of peripheral nerves in leprosy. Skeletal Radiol 29:142-150, 2000

13. Missall TA, Burkemper NM, Jensen SL, Hurley MY: Immunohistochemical differentiation of four benign eccrine tumors. J Cutan Pathol 36:190-196, 2009

14. Murphey MD, Smith WS, Smith SE, Kransdorf MJ, Temple HT: From the archives of the AFIP. Imaging of musculoskeletal neurogenic tumors: radiologic-pathologic correlation. Radiographics 19:1253-1280, 1999

15. Nahra ME, Bucchieri JS: Ganglion cysts and other tumor related conditions of the hand and wrist. Hand Clin 20:249260, v, 2004

16. Park HR, Im SB, Kim HK, Shin DS, Park YL: Painful eccrine spiradenoma containing nerve fibers: a case report. Dermatology 224:301-306, 2012

17. Pérez-López C, Gutiérrez M, Isla A: Inflammatory pseudotumor of the median nerve. Case report and review of the literature. J Neurosurg 95:124-128, 2001

18. Pilavaki M, Chourmouzi D, Kiziridou A, Skordalaki A, Zarampoukas T, Drevelengas A: Imaging of peripheral nerve sheath tumors with pathologic correlation: pictorial review. Eur J Radiol 52:229-239, 2004

19. Rekhi B, Agarwal A: Cytopathologic features of an unusual case of multiple eccrine spiradenomas misdiagnosed as a malignant round cell tumor. J Cytol 34:39-42, 2017

20. Skovronsky DM, Oberholtzer JC: Pathologic classification of peripheral nerve tumors. Neurosurg Clin N Am 15:157-166, 2004

21. Stokvis A, van der Avoort DJ, van Neck JW, Hovius SE, Coert JH: Surgical management of neuroma pain: a prospective follow-up study. Pain 151:862-869, 2010

22. Tagliafico A, Altafini L, Garello I, Marchetti A, Gennaro S, Martinoli C: Traumatic neuropathies: spectrum of imaging findings and postoperative assessment. Semin Musculoskelet Radiol 14:512-522, 2010

23. Watson J, Gonzalez M, Romero A, Kerns J: Neuromas of the hand and upper extremity. J Hand Surg Am 35:499-510, 2010

\section{Disclosures}

The authors report no conflict of interest concerning the materials or methods used in this study or the findings specified in this paper.

\section{Author Contributions}

Conception and design: Heiss. Acquisition of data: Heiss, Scott, Patronas, Quezado. Analysis and interpretation of data: Heiss, Donaldson, Cantor, Patronas, Quezado. Drafting the article: Heiss, Donaldson, Cantor. Critically revising the article: Heiss, Cantor. Reviewed submitted version of manuscript: Heiss, Donaldson, Cantor, Patronas, Quezado. Administrative/technical/ material support: Heiss, Scott. Study supervision: Heiss.

\section{Correspondence}

John D. Heiss, National Institutes of Health, Surgical Neurology Branch, National Institute of Neurological Disorders and Stroke, 10 Center Dr., Rm. 3D20, MSC-1414, Bethesda, MD 20892-1414. email: heissj@ninds.nih.gov. 